\title{
Common Listening Challenges: Indonesian EFL Learners' Perception
}

\author{
Lidiyatul Izzah 1), Khodijah Keeya 2) \\ 1), 2) Universitas Muhammadiyah Jakarta, South Tangerang, Banten, Indonesia \\ 1) lidiyatul.izzah@umj.ac.id, 2) keeyakhodijah@gmail.com
}

\begin{abstract}
Being a major part of internationalizing higher education, teaching English taps particular general cognitive abilities. It is mainly regarding listening that is hypothesized to have a higher influence on acquisition of foreign language. The aim of this study was to identify the common listening challenges experienced by Indonesian EFL learners. This research was practical research using descriptive methods of quantitative research. Subject of the study were subsequently randomly chosen, in which EFL learners at even semesters become the representative. In collecting data, the researchers used a selfstructured questionnaire that refers to three primary categories: (1) the listener, (2) the passage, and (3), the physical setting. The data was then statistically evaluated by referring to Likert type scales, to discover useful information. After all, the finding showed that distortions, lexis recognition, phonological awareness, complexity of the passage and the speech rate highlighted a high degree response of common listening challenges. The significance of the study expected to contribute learners with a better understanding and propose new ideas for acceptable teaching listening.
\end{abstract}

Keywords: EFL, Indonesian learners, listening difficulties, listening challenges

Citation APA Style: Izzah, L., \& Keeya, K. (2019). Common Listening Challenges:

Indonesian EFL Learners' Perception. English Language in Focus (ELIF), 1(2), 95-106.

\section{INTRODUCTION}

I $\mathrm{n}$ the fourth education era, issues linked to learning English seemed to remain the latest topic. To be able to preserve its status, English has always to be taken up either as an official language or as a priority in a country's foreign language teaching (Crystal, 2003). Recently, along with efforts to build up this interconnection, all leading universities have started commercializing English as a medium of instruction. This situation appears to be the right competitive effort to advance their quality and consistency around the globe.

Being a major part of internationalizing higher education, teaching English taps several general cognitive skills. It is primarily about listening that considered more valuable and frequently used than three other 
macro skills. In a research undertaken by Feyten (1991), it was found that individuals spend over forty-five percent of their normal daily life in listening. This rate has dominated the use of any other single language skills, in which nine percent for writing, sixteen percent for reading, and thirty percent for speaking. The findings, furthermore, hypothesize that listening skills naturally have a greater impact on foreign language acquisition. Through this receptive skill, learners can internalize and generate language data within a communicative discourse (Wang, 2018).

Assuming that listening is such a simple act, Peterson (2001) believes "no other type of language input is easy to process as spoken language, received through listening...." (p. 87). Listening is thus fundamentally a vehicle of all language learning, mainly English which is closely related to 'native tongue acquisition' (Mckenzie-Brown, 2012; Rost, 2001; Vandergrift, 2006). Taylor (1964) as cited in Siegel (2015), estimated that close to ninety percent of the high schools and colleges are likely to spend in listening to lectures or discussions. Listening, therefore, plays an important role in measuring communicative language proficiency, either in academic (Prince, 2014; Wang, 2018) or global testing.

On the contrary, despite the significance of listening, this skill is considered one of the most 'Cinderella Skill' (Flowerdew \& Miller, 2005), 'Forgotten Skills' (Downs, 2008), "ignored skill" (Afrin, 2011; Ulum, 2015), mysterious 'black box' skill (Rost, 2001), or "overlooked dimensions" (Feyten, 1991) in certain second language learning. In addition, this skill is considered brings a series of teacher's challenges (Field, 2008; Guo \& Wills, 2005; Renandya \& Farrell, 2011), including the shortest language teaching, the hardest language measurement, and the ineffective learning strategy. Similar studies found that most teachers prefer to implement on 'listening, answering, and checking', rather than 'how' to listen through easy-to-follow strategies (Nemtchinova, 2013) both in a conventional materials or hypermedia (Turel, 2014).

Apart from teacher's challenges, different researchers found that learners commonly experienced multiple challenges during learning listening. In line with Underwood's study, Rubin (1994) shared the common challenges into different factors, namely (1) textual features in parts of listening or visual support, (2) interlocutor features or speaker personal characteristics, (3) task features that correlated to its purpose and response, (4) listener's features that references to listener's personal characteristics, and (5) process features in which listener's cognitive and speaker interact. In reference to Rubin's theory, Mangiafico (1996) as cited in Turel (2014) briefly divides these challenges into two main factors, (1) internal listener's factors - such as, listener's age, level of intelligent, strategies, prior knowledge, and soon, (2) external listener's factors - such speaker characteristic, textual characteristic, and contextual factors.

Based on the statement description, the writers conducted a study to determine the common challenges faced by L2 learners in 
listening comprehension. The current study focuses on three main categories that affect second language listening comprehension: (1) the listener, (2) the passage, and (3), the physical Setting. The significance of the study expected to contribute learners with a better understanding and propose new ideas for acceptable teaching listening.

\section{The Listener}

Comprehending a foreign language taps several cognitive skills, mainly for listeners with greater working memory capacity that contributes greatly to listening comprehension. For instance, in determining what 'signals' are important and in processing, storing, and retrieving the incoming information (Baddeley \& Hitch, 1974; Harrington \& Sawyer, 1992; Miyake \& Friedman, 1988). More recent theoretical models further point out the significant role of working memory in increasing learner's ability to successfully or efficiently resolve misunderstanding of the spoken text. McDonald (2006) found that the memory performance range also L2 correlated significantly with the level of accuracy of the spoken L2 sentence grammar. Although all competence skills show distinctions in terms of modalities, the processing performance required shows the similarity of the underlying cognitive tasks: understanding or integrating information online and organizing knowledge from both syntactic structures and semantic content.

In addition to these general cognitive skills, several factors further contributing to experience with the L2 listeners. These factors include background knowledge about the topic, text, structure, genre, culture, and other schemas (Brown, 2007; Bodie, Worthington, Imhof, \& Cooper , 2008; Rost \& Wilson, 2013). Related to the culture and schema, since that language is the cultural product, so that interpretation, schemata, and scripts are surely based on a certain culture (Tschirner, 2001). Graham (2006) argued that since the listeners are likely to have different cultures, being a nonnative with the unfamiliar topic can be a challenge in understanding the meaning of listening to surface text.

Hymes (1972) as cited in Bloomfield et al (2010) identified eight component that require second language listeners background knowledge. These component consist of: (1) the Setting/scene, (2) the participants in the interpretive community, (3) the objectives of communication, (4) the sequence of communication acts, in which can be dictated by the message's format and context, (5) the key: register, formality, politeness, power relations, (6) instrumentalities: channel, forms of speech, (7) norms, and (8) genre e.g., passage type.

Another challenge that dealing to listening listening comprehension is items (word/lexis) recognition, including limited familiarity with the word (related to the vocabulary size) and the ability to word in accurate production (related to vocabulary use) (Nation, 2001; Underwood, 1989). Nation (2001) suggested that listeners should have an adequate vocabulary to comprehend a L2 listening text. Adequate vocabulary might be estimated by the number of words a listener needs to know to comprehend a 
representative sample of texts. Furthermore, Hirsh and Nation (1992) as cited in Bloomfield et al (2010) have argued that to comprehend all the primary points in a text, listeners need to know more than 5000 words of vocabulary, they are likely to have a great opportunity of understanding what was said.

Along with the lack of lexical knowledge, phonological awareness also may affect L2 listening comprehension Naturally speakers of all languages do not exactly speak or pronounce the world in the same way. Further, the inability to identify L2 prototypical phonemes that do not exist in the native phoneme inventory becomes another challenge faced by learners to process sound meaning (Rixon, 1986; Rost, 2001). In addition to the segmentation of speech stream, Yen (1987) as cited in Assaf (2015) listed that speech discrimination can also be the most prominent challenges for L2 listeners to comprehend.

Moreover, Ur (1984) stated that the important markers of pronunciation namely stress, intonation, and rhythm of diverse spoken English also become other challenges to listen to key information about syntactic grouping. For example speech dis-fluency in spontaneous conversations, including false starts, any variety of breaks, irregularities pause, or non-lexical utterances such as 'um', 'well', 'like', that may affect comprehension (Gilmore, 2007). Goh (2000) also revealed that one of the challenges experienced by learners is 'the encoding of the acoustic or written message, which involves segmenting phonemes from the continuous speech stream in listening' (p.59). As a result, when selecting listening materials, the teacher should provide the listening text with high-quality speech and suprasegmental that differ depending on learners' language level.

Listener's anxiety or distraction can also impact their ability to accurately determine what was said, so that their comprehension decline, even in the native language (Bloomfield et al., 2010; Ur, 1984). There are several factors that influence in listeners' anxiety, such as when in a new situation, the new or too complex information, or think their performance reflects their abilities /Intelligence, inability to take notes, etc (Ching-Shyang Chang \& Read, 2008; Xu, 2011). In addition, since the learners prefer to interpret each word rather than the overall meaning, intolerant to vagueness and incompleteness of understanding was another challenge (Underwood, 1989).

\section{The Passage}

Studies directly examining the effect of passage length on L2 listening comprehension become one challenging factor involved in L2 listening comprehension. (Ilhan, 2018; Mohamadi, 2013). Longer passages including duration, number of syllables, number of words, and number of sentences may be more likely to interfere with listening comprehension because the listeners' working memory storage capacity is enormous (Henning, 1990). Moreover, the longer passage is, the more information listeners could miss after finding the information they do not understand. Rupp, Garcia, \& Jamieson (2001) studied the impacts of passage 
word count and the average length of sentences on L2 listening comprehension. The preliminary analysis showed that the length of longer sentence length predicted more challenging listening comprehension items, and a second analysis discovered that both the quantity of word count of the passage and sentence length contributed to item difficulty. Rupp et al., (2001) also argued that average sentence length likely increased item difficulty due to the greater syntactic complexity of longer sentences, not because longer sentences merely offered more information to handle.

\section{Redundancy improves}

comprehension, but the impact depends on both on the proficiency of the listener and the type of redundancy. It involves repeating key information through repetition, interpretation, and elaboration (Chaudron, 1983). In various passage types (e.g., both conversations and lectures), speakers will return to the points previously introduced to check their audiences' understanding, or simply reaffirm what they consider most important (Field, 2008). Redundancy is often categorized as a form of input simplification because it involves rerendering information so that the listener has another chance to comprehend the information, sometimes in a form that is easier to handle or preserve (Chaudron, 1983). Overall, it is important to consider how redundant form with different complexity influence of listeners comprehension with higher and lower skill.

Like passage length, greater information density is believed to make higher cognitive demands of L2 listeners, which may increase the effort involved in listening comprehension (Buck \& Tatsuoka, 1998). Measures of information density involve dividing the quantity of information in a passage by the total number of words or the passage duration (i.e., capturing the way packed a passage is with information, given its length). Literally, information has been described in the number of ways. One way of describing a piece of information is as a content word, consist mostly of nouns, verbs, adjectives, or adverbs (Nissan, DeVincenzi, \& Tang, 1995). Then other way of defining information is a proposition, the smallest unit of knowledge that can stand alone as a separate true-false statement (Dunkel, Henning, \& Chaudron, 1993). It is the information that listeners remember from a text even when they are unable to recall the exact wording of the presented utterances (Eom, 2006 as cited in Bloomfield et al., 2010). In specific ways, Rupp et al (2001) identified propositional density as the number of phrases in a passage consisting of a noun + attributive adjective + prepositional phrase. In sum, information density can be calculated by counting the number of content words or propositions in a passage and dividing by the total number of words or the duration of the passage.

Passage complexity, type, or organization also may affect L2 listening comprehension. Measures of passage complexity refer to such dissimilar properties as syntactic structure, concreteness, and word frequency (Assaf, 2015). Regarding studies on syntactic structure, Bloomfield et al., (2010) specifically classified kinds of passage complexity that impact Listening 
comprehension, namely the degree of subordination or the number of negatives, dependent clauses, and references in the passage. Additional measures appeal to the extent to which a listener must use pragmatic knowledge, coherence, and discourse markers. Some studies show that organization or type of passage can influence listening comprehension because of its effect on working memory loads. The effect of L2 listening comprehension is as varied as the conceptualization of the type of listening to itself, oral text such as dialogue is likely easier for L2 listeners than for more literate texts such as news reports.

\section{The Physical Setting}

Research shows that speaker body movement and accent make listening task more challenging. Listening fundamentally becomes difficult while learners listen to the recording. As stated by Brown (1995), interlocutor's body movement and stressed syllables are interrelated. Not seeing the interlocutor body movement and facial expression, therefore, becomes the difficult one. In conjunction with speaker's body movement, Major, Fitzmaurice, Bunta, \& Balasubramanian (2002) reported that several auditory features including the unfamiliarity of the speaker's accent also become a single determiner of difficulty in listening comprehension.

Severail dimension of physical setting affect comprehension, including noises and distortions. Watson \& Smeltzer (1984) pointed out that other listening comprehension challenges were noises or distortions, whether originated from the surrounding environment or the ones that emerged from the listening equipment. Bloomfield et al., (2010) added that noise or distortion in the audio signal certainly interferes either for first language or second language listeners, although the effect is greater for L2 listeners. For L2 listeners, noise is most similar to signals (e.g., babble noise when listening to the recording) presents the biggest challenge for listeners. Other types of distortion (e.g. white noise, highfrequency information filtering [as is often the case with telephone calls], and time compression) differently affect speech perception and processing.

Along with speaker's accent, the faster speech rate, whether computermanipulated or naturally produced, tends to hinder listening comprehension, even in the advanced listener (Koch \& Janse, 2016; Larsen-Freeman \& Long, 2014; Underwood, 1989). However, several studies have shown that speaking speed is not a major determinant of understanding difficulties. In addition, even though a faster speech rate can damage L2's listening comprehension, slower speaking speeds may not necessarily be beneficial or become the audience's first choice (Bloomfield et al., 2010). For this reason, the teachers should use pausing while giving lecturer. The pauses activity can give second language learners additional note-taking or processing time and act as cues about the speaker's upcoming utterances.

\section{RESEARCH METHODOLOGY}

7 his research is practical research that uses descriptive
quantitative research methods. The purpose of this study was to determine the common listening 
challenges faced by EFL learners in Indonesia. Besides, the population of the study consisted of all learners in the English Department, Muhammadiyah University of Jakarta, Indonesia. Thereafter, subjects of the study were randomly selected, in which 86 of Indonesian EFL learners at even semesters as the representative.

In collecting data, the researchers used a self-structured questionnaire and it was analyzed statistically by referring to Likert type scales. The items of the questionnaire were mainly adapted from Hakam Asan Assaf (Assaf, 2015). The questionnaire consists of 27 questions items grouped based on three categories; (1) the listener, (2) the passage, and (3), the physical Setting. In analyzing the data, the researcher used percentages descriptive analysis. The average for each item of responses was referring to the
Likert Scale: (\%80-\%100) very high degree of response, (\%70-\%79.9) high degree of response, (\%60-\%69.9) moderate degree of response, (\%50$\% 59.9$ ) low degree of response, and (Less than \%50) very low degree of response

\section{FINDING AND DISCUSSION}

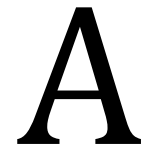
$\mathrm{s}$ mentioned in the previous chapter, the writer conducted the research by using a questionnaire to investigate the common listening challenges that EFL learners faced in listening comprehension. Regarding the research participants, it was found out that 86 learners were actively participated in giving their responses. In describing the research finding, the researchers used descriptive analysis of each statement on percentages.

Table 1. The percentage and effect degree of common listening challenges faced by EFL learners in Indonesia.

\begin{tabular}{|c|c|c|c|}
\hline No & Statement & $\begin{array}{l}\text { Perce } \\
\text { ntage }\end{array}$ & Effect Degree \\
\hline 1. & $\begin{array}{l}\text { I find it hard to comprehend texts that represent too many unfamiliar } \\
\text { words }\end{array}$ & 73 & High \\
\hline 2. & I feel tired when I listen to along spoken text. & 67 & Moderate \\
\hline 3. & To comprehend the spoken text, I'm used to use my prior knowledge. & 78 & High \\
\hline 4. & I find it hard to comprehend every single word of incoming speech. & 59 & Low \\
\hline 5. & I find it hard to comprehend the whole listening passage. & 57 & Low \\
\hline 6. & I find pronunciation familiar but cannot recognize the words. & 63 & Moderate \\
\hline 7. & I cannot recognize words I know while learning. & 56 & Low \\
\hline 8. & $\begin{array}{l}\text { I stop listening and start thinking about the meaning of the words } \\
\text { when encountering an unknown word }\end{array}$ & 66 & Moderate \\
\hline 9. & I find difficulty infer the meaning of an unknown word while listening. & 67 & Moderate \\
\hline 10. & $\begin{array}{l}\text { I find it difficult to follow the sequence of the spoken text when the } \\
\text { sentences are too long and complex. }\end{array}$ & 64 & Moderate \\
\hline 11. & I lose focus of the talk when I have an expected answer in my mind. & 61 & Moderate \\
\hline 12. & $\begin{array}{l}\text { I am unable to concentrate because I look for the answer and listen to } \\
\text { the dialogue at the same time. }\end{array}$ & 68 & Moderate \\
\hline 13. & I lose my concentration if the recording is in poor quality. & 77 & High \\
\hline 14. & $\begin{array}{l}\text { I find it difficult to predict what would come next at the time of } \\
\text { listening. }\end{array}$ & 67 & Moderate \\
\hline
\end{tabular}




\begin{tabular}{|c|c|c|c|}
\hline 15. & I stop listening when I have problems in understanding a listening text. & 58 & Low \\
\hline 16. & I feel anxious when I listen to spoken texts. & 57 & Low \\
\hline 17. & I find listening comprehension difficult when I am not interested. & 59 & Low \\
\hline 18. & I find listening comprehension difficult when I feel tired. & 49 & Very Low \\
\hline 19. & $\begin{array}{l}\text { I find difficult to understand the natural speech which is full of } \\
\text { hesitation and pauses. }\end{array}$ & 66 & Moderate \\
\hline 20. & $\begin{array}{l}\text { I find it difficult to understand the meaning of the words which are not } \\
\text { pronounced clearly. }\end{array}$ & 74 & High \\
\hline 21. & I have difficulty understanding speakers with unfamiliar accents. & 73 & High \\
\hline 22. & I find it difficult to understand when the speaker talks too fast. & 74 & High \\
\hline 23. & $\begin{array}{l}\text { I find it difficult to understand the recorded material if it is not } \\
\text { repeated. }\end{array}$ & 63 & Moderate \\
\hline 24. & I find it difficult to concentrate with noises around. & 78 & High \\
\hline 25. & $\begin{array}{l}\text { I find it difficult to understand English when there unclear sound } \\
\text { resulting from a poor quality CD player. }\end{array}$ & 79 & High \\
\hline 26. & I find it difficult to concentrate when the room is not conditioned. & 69 & Moderate \\
\hline 27. & $\begin{array}{l}\text { I find it difficult to understand English when there are unclear sounds } \\
\text { resulting from poor acoustic conditions of the classroom. }\end{array}$ & 80 & Very High \\
\hline
\end{tabular}

As can be seen clearly from the table, it has been noticed that the statement (27) got a very high effect degree $80 \%$ that dominating other statements. It can be explained that unclear sounds resulting from poor acoustic conditions become the highest challenge to listeners. Along with the poor acoustic conditions, the effect degree is high for statements $(1,3,13$, $20,21,22,24$, and 25) with average percentage of $70 \%$. This percentage affirms that unfamiliar words, word obscurity, the infallibility of accents, and the faster speech rate are components of the common challenge learners faced in listening comprehension. Most of the learners also assume that unclear pronunciation seems to place an extra burden on their listening. For the following reasons, learners as were experienced to necessary activate their background knowledge for comprehending the text.

On the other hand, the statements of $(2,6,8,9,10,11,12,14,19$, and 23$)$ statements are categorized as moderate, with $60 \%$ on average percentage. The finding shows that learners partially find that it is uneasy to infer meaning correctly, mainly with a long and complex of spoken text. Referring to the passage, it found that repeating key information also becomes backwardness and incompleteness to wholly comprehend the text. Most learners agree that answering questions and listening to dialogue at the same time, partly affect their attention to the recording. Moreover, they also lack predicting strategy about what is going to happen or what the speaker might say next (the speaker's intentions). Regarding the physical setting, at any moderate degree, the unconditioned room also becomes challenging factors of the learner.

After all, six statements $(4,5,7$, 15,16 , and 17) of the questionnaire result got low degree response, with an average percentage of $50 \%$. These items point out that few learners feel anxious or 
uninterested to listen when a task is too difficult or unfamiliar. Besides, a small number of learners think that they are unable to understand every single word of the whole listening passage. Then, few of them prefer to stop listening when texts are not clear in the spoken text. Finally, For the following reasons, fatigue is not a serious challenge for the learners. The percentage of this statement (18) was $49 \%$. In sum, all the statements imply that the place where learners listen and the quality of the listening equipment plays a crucial role in listening comprehension.

\section{CONCLUSION}

indings of the study show that there
are many factors that contribute to the difficulties in listening comprehension. (1) Regarding listeners, the lack of lexical knowledge become one of the most challenging to comprehend the whole listening passage. It must also be noted that the inability to identify L2 phonemes become another challenge faced by learners to process sound meaning. With the Exception of lexical recognition and phonological awareness, most learners agree that using their background knowledge is a significant way to solve the problem. (2) Regarding the passage, a long and complex of the spoken text identified become the most challenging listening items.

Regarding the physical setting, it can be reported that unclear sounds resulting from poor acoustic conditions become the highest challenge to listeners. In sum, it implies that the place where learners listen and the quality of the listening equipment play a crucial role in listening comprehension. Besides, the unfamiliarity of the speaker's accent and the faster speech rate also become the component determiners of item challenging in listening comprehension.

\section{REFERENCES}

Assaf, A. H. (2015). The Difficulties Encountered by EFL Learners in Listening Comprehension as Perceived by ELC Students at the Arab American University-Jenin. Palestine: An-Najah National University.

Bloomfield, A., Wayland, S. C., Rhoades, E., Blodgett, A., Linck, J., \& Ross, S. (2010). What Makes Listening Difficult? Factors Affecting Second Language Listening Comprehension. Maryland: University of Maryland.

Bodie, G. D., Worthington, D., Imhof, M., \& Cooper, L. O. (2008). What Would a Unified Field of Listening Look Like? A Proposal Linking Past Perspectives and Future Endeavors. International Journal of Listening, 22(2), 103-122. https://doi.org/10.1080/10904010 802174867

Brown, G. (1995). Dimensions of Difficulty in Listening Comprehension. In D. J. Mendelsohn \& J. Rubin (Eds.), A Guide for the Teaching of Second Language Listening (pp. 11-15). Canada, USA: Dominie Press.

Buck, G., \& Tatsuoka, K. (1998). Application of the Rule-space Procedure to Language Testing: Examining Attributes of a Free Response Listening Test. Language Testing, 15(2), 119-157. https://doi.org/10.1177/02655322 9801500201

Chaudron, C. (1983). Simplification of Input: Topic Reinstatements and Their Effects on L2 Learners' 
Recognition and Recall. TESOL Quarterly, 17(3), 437-458.

Ching-Shyang Chang, A., \& Read, J. (2008). Reducing Listening Test Anxiety Through Various Forms of Listening Support. TESL-EJ, 12(1).

Crystal, D. (2003). English as a Global Language (2nd Ed). Cambridge: Cambridge University Press.

Downs, L. J. (2008). Listening Skills Training. Alexandria: ASTD Press.

Dunkel, P., Henning, G., \& Chaudron, C. (1993). The Assessment of an L2 Listening Comprehension Construct: A Tentative Model for Test Specification and Development. The Modern Language Journal, 77(2), 180-190.

https://doi.org/10.2307/328942

Feyten, C. M. (1991). The Power of Listening Ability: An Overlooked Dimension in Language Acquisition. The Modern Language Journal, 75(2), 173-180. https://doi.org/10.2307/328825

Field, J. (2008). Listening in the Language Classroom. Cambridge: Cambridge University Press.

Flowerdew, J., \& Miller, L. (2005). Second Language Listening: Theory and Practice. New York: Cambridge University Press.

Gilmore, A. (2007). Authentic Materials and Authenticity in Foreign Language Learning. Language Teaching, 40(2), 97-118. https://doi.org/10.1017/S0261444 807004144

Goh, C. C. (2000). A cognitive perspective on language learners' listening comprehension problems. System, 28(1), 55-75. https://doi.org/10.1016/S0346251X(99)00060-3

Golchi, M. M. (2012). Listening Anxiety and Its Relationship with Listening Strategy Use and Listening
Comprehension among Iranian IELTS Learners. International Journal of English Linguistics, 2(4), 115-128.

https://doi.org/doi:10.5539/ijel.v2 n4p115

Graham, S. (2006). Listening Comprehension: The Learners' Perspective. System, 34(2), 165-182. https://doi.org/10.1016/J.SYSTEM. 2005.11.001

Guo, N., \& Wills, R. (2005). An Investigation of Factors Influencing English Listening Comprehension and Possible Measures for Improvement (1-16). AARE Annual Conference. Retrieved from https://www.aare.edu.au/

Harrington, M., \& Sawyer, M. (1992). L2 Working Memory Capacity and L2 Reading Skill. Studies in Second Language Acquisition, 14(1), 25-38.

Henning, G. (1990). A Study of the Effects of Variation of Short-Term Memory Load, Reading Response Length, and Processing Hierarchy on TOEFL Listening Comprehension Item Performance. In ETS Research Report Series (Vol. 1990). https://doi.org/10.1002/j.23338504.1990.tb01354.x

Ilhan, B. (2018). Length in listening texts as a single determiner of difficulty for comprehension. Journal of Language and Linguistic Studies, 14(3), 336-346.

Koch, X., \& Janse, E. (2016). Speech rate effects on the processing of conversational speech across the adult life span. Acoustical Society of America, 139(4), 1618-1636. https://doi.org/10.1121/1.4944032

Larsen-Freeman, D., \& Long, M. H. (2014). An Introduction to Second Language Acquisition Research. New York: Routledge.

Major, R. C., Fitzmaurice, S. F., Bunta, F., \& Balasubramanian, C. (2002). The 
Effects of Nonnative Accents on Listening Comprehension: Implications for ESL Assessment. TESOL Quarterly, 36(2), 173. https://doi.org/10.2307/3588329

Markham, P., \& Latham, M. (1987). The Influence of Religion-Specific Background Knowledge on the Listening Comprehension of Adult Second-Language Students. Language Learning, 37(2), 157-170. https://doi.org/10.1111/j.14671770.1987.tb00563.x

McDonald, J. L. (2006). Beyond the Critical Period: Processing-Based Explanations for Poor Grammaticality Judgment Performance by Late Second Language Learners. Journal of Memory and Language, 55(3), 381401.

https://doi.org/10.1016/j.jml.2006. 06.006

Mckenzie-Brown, P. (2012). Reflections on Communicative Language Teaching: A Course Book for Teaching English as a Foreign Language. Independent Publishing.

Miyake, A., \& Friedman, N. P. (1988). Individual Differences in Second Language Proficiency: Working Memory as Language Aptitude. In A. F. Healy \& L. E. Bourne (Eds.), Foreign Language Learning: Psycholinguistic Studies on Training and Retention (pp. 318-338). New Jersey: Lawrence Erlbaum Associates, Inc.

Mohamadi, Z. (2013). Determining the Difficulty Level of Listening Tasks. Theory and Practice in Language Studies, 3(6), 987-994. https://doi.org/10.4304/tpls.3.6.98 7-994

Nation, I. S. P. (2001). Learning Vocabulary in Another Language. Cambridge: Cambridge University Press.
Nemtchinova, E. (2013). Teaching Listening. In TESOL International Association. Virginia: TESOL International Association.

Nguyen, C.-D., \& Newton, J. (2018). Schemata in Listening Comprehension. In J. I. Liontas (Ed.), The TESOL Encyclopedia of English Language Teaching (pp. 1-7). https://doi.org/10.1002/97811187 84235.eelt0592

Nissan, S., DeVincenzi, F., \& Tang, K. L. (1995). An Analysis of Factors Affecting the Difficulty of Dialogue Items in TOEFL Listening Comprehension. ETS Research Report Series, 1995(2), i-42. https://doi.org/10.1002/j.23338504.1995.tb01671.x

Peterson, P. W. (2001). Skills and Strategies for Proficient Listening. In M. Celce- Murcia (Ed.), Teaching English as Second or Foreign Language (pp. 65-85). Boston: Heinle \& Heinle.

Preiss, R. W., \& Wheeless, L. R. (1989). Affective Responses in Listening: A Meta-Analysis of Receiver Apprehension Outcomes. International Listening Association. Journal, 3(1), 72-102. https://doi.org/10.1207/s1932586 xij10301_8

Prince, P. (2014). Listening Comprehension: Processing Demands and Assessment Issues. In P. Leclercq, A. Edmonds, \& H. Hilton (Eds.), Measuring L2 Proficiency: Perspectives from SLA (pp. 93-108). Canada: Multilingual Matters.

Renandya, W. A., \& Farrell, T. S. C. (2011). "Teacher, the tape is too fast!" Extensive listening in ELT. ELT Journal, 65(1), 52-59. https://doi.org/10.1093/elt/ccq015 Rixon, S. (1986). Developing Listening Skill. London: Macmillan.

Rost, M. (2001). Listening. In R. Carter \& 
D. Nunan (Eds.), The Cambridge Guide to Teaching English to Speakers of Other Languages (pp. 713). UK: Cambridge University Press.

Rost, M., \& Wilson, J. (2013). Active listening. New York: Routledge.

Rubin, J. (1994). A Review of Second Language Listening Comprehension Research. The Modern Language Journal, 78(2), 199. https://doi.org/10.2307/329010

Rupp, A. A., Garcia, P., \& Jamieson, J. (2001). Combining Multiple Regression and CART to Understand Difficulty in Second Language Reading and Listening Comprehension Test Items. International Journal of Testing, 1(34), 185-216. https://doi.org/10.1080/15305058. 2001.9669470

Schmidt-Rinehart, B. C. (1994). The Effects of Topic Familiarity on Second Language Listening Comprehension. Modern Language Journal, 78(2), 179-189.

Siegel, J. (2015). Exploring Listening Strategy Instruction through Action Research. Basingstoke, UK: Palgrave Macmillan.

Tschirner, E. (2001). Language Acquisition in the Classroom: The Role of Digital Video. Computer Assisted Language Learning, 14(34), 305-319. https://doi.org/10.1076/call.14.3.3 05.5796

Turel, V. (2014). Factors Affecting Listening. In C. M. Akrivopoulou \& N. Garipidis (Eds.), Human Rights and the Impact of ICT in the Public Sphere: Participation, Democracy, and Political Autonomy: Participation, Democracy, and Political Autonomy (pp. 310-331). New York: IGI Global.

Ulum, Ö. G. (2015). Listening: The
Ignored Skill in EFL Context. International Journal of Humanities Social Sciences and Education (IJHSSE), 2(5), 72-80. Retrieved from www.arcjournals.org

Underwood, M. (1989). Teaching Listening. New York: Longman.

Ur, P. (1984). Teaching Listening Comprehension. Cambridge: Cambridge University Press.

Vandergrift, L. (2006). Second Language Listening: Listening Ability or Language Proficiency? The Modern Language Journal, 90(1), 6-18. https://doi.org/10.2307/3588811

Vandergrift, L. (2007). Recent Developments in Second and Foreign Language Listening Comprehension Research. Language Teaching, 40(3), 191-210. https://doi.org/10.1017/S0261444 807004338

Wang, H. (2018). Testing Lecture Comprehension Through Listeningto-summarize Cloze Tasks: The Trio of Task Demands, Cognitive Processes and Language Competence. Singapore: Springer.

Watson, K. W., \& Smeltzer, L. R. (1984). Barriers to Listening: Comparison between Students and Practitioners. Communication Research Reports, 1(1), 82-87.

$\mathrm{Xu}, \mathrm{F}$. (2011). Anxiety in EFL Listening Comprehension. Theory and Practice in Language Studies, 1(12), 17091717.

https://doi.org/10.4304/tpls.1.12.1 709-1717 